\title{
Synaptic scaling enables dynamically distinct short- and long-term memory formation
}

\author{
Christian Tetzlaff' ${ }^{1,24^{*}}$, Christoph Kolodziejski ${ }^{1,3,4}$, Marc Timme ${ }^{1,3,4}$, Misha Tsodyks ${ }^{5}$, Florentin Wörgötter ${ }^{2,4}$ \\ From Twenty Second Annual Computational Neuroscience Meeting: CNS*2013 \\ Paris, France. 13-18 July 2013
}

Memory formation in the nervous system relies on mechanisms acting on time scales from minutes, for long-term synaptic plasticity [1], to days, for memory consolidation [2]. During such processes, the neural network distinguishes synapses relevant for forming a longterm storage (LTS), which are consolidated, from synapses of short-term storage (STS), which fade. How time scale integration and synaptic differentiation is simultaneously achieved within one neural circuit remains unclear. We show in simulations and mean-field analyses that synaptic scaling [3] - a slow process usually associated with the maintenance of activity homeostasis combined with the faster processes of synaptic plasticity simultaneously achieve both, thereby providing a natural separation of short- from long-term storage. A network intrinsic bifurcation enables this separation as this bifurcation induces different response properties of previously learned cell assemblies due to external memory reactivations. These reactivations could be associated with "sleeplike" activations as, for instance, sharp-wave ripples during slow-wave sleep $[4,5]$. Additionally, the interaction between plasticity and scaling provides an explanation for an established paradox where memory consolidation and destabilization critically depends on the exact order of learning and recall. This enables us to reproduce humanpsychophysical results [6] on the apparently paradoxical effect of memory destabilization due to memory recall [7]. However, other experimentalists failed to reproduce this memory destabilization effect (e.g., [8]). This ambivalence can be explained by the here proposed bifurcation scenario as the initial conditions and exact timings of recall and learning determine the transition between consolidation and destabilization. Thus, the dynamics of our

\footnotetext{
* Correspondence: tetzlaff@physik3.gwdg.de

${ }^{1}$ Network Dynamics Group, Max Planck Institute for Dynamics and Self-

Organization, Göttingen, Germany

Full list of author information is available at the end of the article
}

model yield the fact that memory - similar to the real systems - remains susceptible to perturbations and has to be repeatedly consolidated [2] which could happen during sleep $[4,5]$. To achieve a final stabilization of memory, systems consolidation, which also begins during sleep [4], performs a transition from a dynamic to a more static memory representation by transferring the information to the neocortex [2]. The processes suggested here are capable of repeatedly (re)consolidating LTS-synapses, while STS-candidates fade. This may thus essentially contribute to providing a stable substrate for systems consolidation.

\section{Author details \\ ${ }^{1}$ Network Dynamics Group, Max Planck Institute for Dynamics and Self- Organization, Göttingen, Germany. ${ }^{2}$ Institute for Physics III - Biophysics, Georg-August University, Göttingen, Germany. ${ }^{3}$ Institute for Physics, Nonlinear Dynamics, Georg-August University, Göttingen, Germany. ${ }^{4}$ Bernstein Center for Computational Neuroscience, Göttingen, Germany. ${ }^{5}$ Weizmann Institute, Rehovot, Israel.}

Published: 8 July 2013

\section{References}

1. Bliss TVP, Lomo T: Long-lasting potentiation of synaptic transmission in the dentate area of the anaesthetized rabbit following stimulation of the perforant path. J Physiol 1973, 232:331-356.

2. Dudai $Y$ : The neurobiology of consolidation, or, how stable is the engram? Annu Rev Psychol 2004, 55:51-86.

3. Turrigiano GG, Leslie KR, Desai NS, Rutherford LC, Nelson SB: Activitydependent scaling of quantal amplitude in neocortical neurons. Nature 1998, 391:892-896.

4. Diekelmann S, Born J: The memory function of sleep. Nat Rev Neurosci 2010, 11:114-126.

5. Chauvette S, Seigneur J, Timofeev I: Sleep oscillations in the thalamocortical system induce long-term neuronal plasticity. Neuron 2012, 75:1105-1113.

6. Walker MP, Brakefield T, Hobson JA, Stickgold R: Dissociable stages of human memory consolidation and reconsolidation. Nature 2003, 425:616-620.

7. Nader K, Schafe GE, LeDoux JE: Fear memories require protein synthesis in the amygdala for reconsolidation after retrieval. Nature 2000, 406:722-726.
() Biomed Central

(c) 2013 Tetzlaff et al; licensee BioMed Central Ltd. This is an Open Access article distributed under the terms of the Creative Commons Attribution License (http://creativecommons.org/licenses/by/2.0), which permits unrestricted use, distribution, and reproduction in any medium, provided the original work is properly cited. 
8. Cammarota M, Bevilaqua LR, Medina LRM, Izquierdo I: Retrieval does not induce reconsolidation of inhibitory avoidance memory. Learn Mem 2004, 11:572-578.

doi:10.1186/1471-2202-14-S1-P415

Cite this article as: Tetzlaff et al:: Synaptic scaling enables dynamically distinct short- and long-term memory formation. BMC Neuroscience 2013 14(Suppl 1):P415.

Submit your next manuscript to BioMed Central and take full advantage of:

- Convenient online submission

- Thorough peer review

- No space constraints or color figure charges

- Immediate publication on acceptance

- Inclusion in PubMed, CAS, Scopus and Google Scholar

- Research which is freely available for redistribution

Submit your manuscript at www.biomedcentral.com/submit

Biomed Central 